\title{
Self-Employment and Entrepreneurship: A Theoretical Approach
}

\author{
Jolanta Szaban ${ }^{1}$, Małgorzata Skrzek-Lubasińska²
}

Submitted: 20.11.17. Final acceptance: 15.03.18

\section{Abstract}

Purpose: The purpose of this article is to position self-employment within an entrepreneurship paradigm. The authors create a structured approach to the existing concepts and definitions of entrepreneurship and self-employment, as well as interrelations between them. The text proposes a framework to analyze these two phenomena by establishing their categorization.

Methodology: An in-depth critical review of selected literature of the classical and contemporary entrepreneurship theories and definitions in the context of self-employment.

Findings: The main results of the study show major discrepancies between existing definitions and approaches in entrepreneurship and self-employment theories and the official EU definitions.

Practical implications: The findings offer a starting point for quantitative, methodologically sound, comparative studies on entrepreneurship and self-employment and their role in the contemporary labor market. The proposed categorization structures current terminological chaos and standardizes the terms and tools used in labor market statistics.

Originality: The article comprises a set of notions related to the concept of both entrepreneurship and self-employment. The text positions self-employment within an entrepreneurship paradigm and offers new arguments in the discussion on their similarities and differences. The summary offers an original idea that confronts self-employment forms with selected entrepreneurship characteristics.

Keywords: entrepreneurship, entrepreneur, self-employment, categorization, definitions

$$
\text { JEL: F66, J2, L2; } 01
$$




\section{Introduction}

In recent years the group of self-employed has grown significantly. This trend is common for many countries while its interpretations differ. Many treat self-employment either as a form of employment or a synonym of entrepreneurship. Others perceive self-employment as a desirable form of economic development or a labor market pathology.

In the Europe 2020 strategy, the European Commission (EC) recognizes entrepreneurship and self-employment as key for achieving smart, sustainable, and inclusive growth. EC declares that the promotion of self-employment and entrepreneurship is an important method of creating new jobs and enhancing labor market opportunities for the unemployed and other disadvantaged social groups. Similarly, the Employment Package adopted in 2012 recognizes the potential of self-employment and entrepreneurship in contributing to a job-rich recovery (EU SWD, 2016). In the Europe 2020 strategy, EC treats entrepreneurship and self-employment as separate notions. Another example is the European Social Fund (ESF), which declares that it promotes entrepreneurship through financial and business support services: supporting entrepreneurs and the self-employed (2016). The joint EC and OECD publication entitled Missing Entrepreneurs (2015) focuses on entrepreneurship developments among vulnerable groups: youth, women, migrants, the disabled, or the elderly. Missing Entrepreneurs notes that "actions are needed to increase awareness of opportunities for entrepreneurship and self-employment, to simplify regulations and to ease the transition from welfare to business ownership." OECD paper from 2016 remarks that in some cases "entrepreneur" means the self-employed who employ others. The newest OECD paper from 2017states that "Entrepreneurial activity appears to be recovering from the crisis," as illustrated by the example "of business creation trending upwards and that the number of bankruptcies has fallen." However, as shown above, it is by far not a universal approach even in the European Union and OECD institutions.

A similar inconsistency and blurriness appears in several scientific papers. Numerous researchers consider self-employment a flexible form of employment (Henrekson, 2007; Millán, Congregado and Román, 2010; Congregado, Golpe nad Carmona, 2010; Shane, 2008; Purcell 2000). On the other hand, McKeown and Phillips (2014) suggest that "self-employment is an escape from being employed."

Audretsch, Aranguren and Callejón (2008) explain the increase in the number of self-employed by the fact that many firms substitute ordinary contract system with a "special" type of employment. Hence, many former regular employees become independent legal business entities. Some authors (Cieślik, 2015) suggest that this type of 
new self-employed should not be included in the pure entrepreneurs group. One of the motivations of self-employment is the anticipated reduction of tax and social security contributions (Johansson, 2005; Szaban, 2016), sometimes called "costs optimization." In this context, the self-employment is a symptom of labor market pathology.

Other researchers went even further by equating self-employment to the idea of precarious work (Cranford et al., 2003; Hughes, 2006; Muehlberger, 2007; Kalleberg et al., 2000; Louie etal., 2006; Vosko, 2006; Vosko and Zukewich, 2006; Wall, 2015). The precarious character of self-employment surfaces from the measureable characteristics assessment, such as fewer social benefits, high risk, long working hours, low income, and lack of permanency. Noteworthy, McKeown and Phillips (2014) remark focus on protection and rights seems strangely at odds with the independence and self-sufficiency, which are the main characteristics of self-employment.

As we have seen, the two concepts of self-employment and entrepreneurship often appear jointly because it looks like a person who bears the risk and benefit of independence at work must have entrepreneurial skills and abilities (Guerra and Patuelli, 2016; Cullen, Johnson, and Parboteeah, 2014; Eckhardt and Eade, 2011; Filion, 2011, Demirgüç-Kunt, Klapper and Panos, 2007; Salgado-Banda, 2005; Brown and Uljin, 2004; Douglas and Shepherd, 2000). In this sense, self-employment means entrepreneurship precisely because the self-employed run their own businesses often at their own risk. The self-employed also fill market niches (gaps) and usually respond to the needs of customers more flexibly, quickly, and better than the large companies do.

The authors believe it is necessary to distinguish between entrepreneurship and self-employment if only for practical reasons; for instance, when deciding who can apply for financial support from the state or international organizations. It seems obvious that these institutions mainly consider the hard, measurable, and legal criteria, which means that the applicants should be the formally self-employed and not those who call themselves entrepreneurs.

Many elements in the concept of entrepreneurship arise from the economic, social, and behavioral context (Brown and Ulijn, 2004),which is why this analysis refers and limits itself to these three aspects of entrepreneurship and self-employment. However, this paper does not follow the psychological approaches, personal and demographic traits, or psychological motivation to become an entrepreneur. We are well aware that the psychology of individual entrepreneur occupies a significant place in the entrepreneurship literature and that it is, in fact, one of the most important elements of this pheno- 
menon. All these approaches form important contextual factors of entrepreneurship but deserve separate research.

This article primarily reviews books, articles, and papers about entrepreneurship and its most important characteristics. The authors attempt to answer the key question why the distinction between these two categories is important, what exactly makes them simultaneously similar and different, and why they are often confused with each other. Due to many incoherent concepts about both and their multifacetedness, one cannot apply "real life" cases to clarify the distinction between them. In turn, this makes empirical studies concerning entrepreneurship and self-employment difficult and the obtained results, generally, incomparable. The authors studied entrepreneurship theories to find the characteristic features of entrepreneurial activity. Then, using part of the results of the author's previous study $(2017)^{3}$, this article analyzes the activities of the highly heterogeneous self-employed group. This paper presents the detailed results of the literature review that concerns the classification criteria of the different self-employed groups. The final result is an in-depth analysis of the characteristics of entrepreneurs versus self-employed groups.

\section{Entrepreneurship In Selected Theories: An Interdisciplinary Approach}

The phenomenon of entrepreneurship fascinates researchers from various scientific disciplines for many years. Baumol wrote in 1968 that "the entrepreneur (...) is one of the most elusive characters in the cast that constitutes the subject of economic analysis". Bygrave and Hofer suggested in 1991 that entrepreneurship does not have a substantial theoretical foundation and that the construction of the entrepreneurship theory encounters several obstacles. The main issue comes with the inability to agree the definition of the concept itself. Still, there are practitioners who believe that it is possible to perform empirical research and analyze the "real life" economy without definitions (descriptive approach). Others, like Bygrave and Hofer (1991) argue the exact opposite, that "good science has to begin with good definitions."

Peneder observed in 2009 the interdisciplinary nature of entrepreneurship, in which scholars from the fields of economics, business strategy, organizational behavior, sociology, and psychology approach the matter from the perspective of each of these scientific disciplines. Peneder remarks that both business strategists and management

3 Article sent for publication in 2017. 
academics concentrate on how to act entrepreneurially by applying a behavioral and processual perspective. On the other hand, economists primarily care about how the economic system works and, therefore, characterize entrepreneurship by the particular functions it plays in the whole system. In turn, labor economists predominantly consider the occupational choice as between a salaried job and self-employment. Then, sociologists and scholars of organization studies analyze the entrepreneurial behavior symptoms, while psychologists explain how entrepreneurship relates to personal characteristics.

One may thus say that entrepreneurship indeed is a phenomenon that appears in numerous scientific disciplines, which makes it even more complicated to reach the consensus that concerns both its definition and nature. The main goal of this study is to select the characteristics of entrepreneurship from economic, sociological and management theories conveyed in the literature. Consciously, and not without regret, the authors disregard psychological, cultural, and anthropological theories, even if in some cases they still consider some of their aspects.

Cantillon was the economist who first introduced the term "entrepreneur." Smith quotes Cantillon in his An Inquiry into the Nature and Causes of the Wealth of Nations (1776), although no classical economist reflects on entrepreneurship, as the entrepreneur was for them simply "the man of business" (Ricketts, 2006). However, Cantillon (Casson, 1990; 1991) divided working people into two groups: employees with a fixed income, insured against risk, and those whose income is uncertain and dependent on the results of their own activities. The members of the latter use the market and its resources "to buy cheap and sell high." Cantillon calls the latter entrepreneurs; they differ from the owners of capital. Cantillon thought that the main characteristics of entrepreneurship are risk-bearing and search for market opportunities. Such idea also appears, among others, in Kahneman and Tversky (1979), Kumar et al. (2003), or Landstrom (2010).

One finds no integrated and systematic approach to entrepreneurship in the classical economics represented by Adam Smith. He observed the association between entrepreneurship, risk-taking, and creative activity, which were to be the driving forces of the economy that resulted from increased productivity.

Formaini (2001) presents discussions among classical economists about the person of the entrepreneur: "Some have claimed that Smith's view of the "undertaker was nothing more than the physiocratic entrepreneurial model in English terminology" (Elkjaer et al., 1991, p. 806-807). Others deny that Smith understood or used the entrepreneur 
concept at all (Rothbard 1995). Regardless of this controversy, one may assume that Smith and other classical economists like J.S. Mill and J.B. Say distinguished entrepreneurs into those who take risks, combine productive factors and the possibilities of innovation, and capitalists who provide the means for investment and possess pure capital. They believed that capitalists have money and entrepreneurs need money.

Thuenen (in Blaug, 1994) defines entrepreneurial profits as profit from every economic activity reduced by (1) the percent of invested capital, (2) managers' salaries, and (3) business risk premiums. The entrepreneurial profits result from the incurrence of additional operational risk that no insurance company wants to insure because it is unpredictable (Blaug, 1994). They rather understand this risk as uncertainty.

According to Knight (1921), due to market uncertainty and the necessity to act with incomplete information, each entrepreneurial activity always relates to risk and personal uncertainty. This is an important distinction. Risk is a deviation from what the entrepreneur anticipates. Uncertainty means an unexpected and unpredictable situation, which one cannot insure or avoid. Knight reserves the term of "entrepreneur" for the appraising and uncertainty-bearing producers in already formed business organizations (Gunning, 1993). Knight also introduces the term "ultimate responsibility of the entrepreneur" as not separated from his ultimate control (Kirzner, 1973, p. 83).

Von Mises $(1949,1998)$ argues that "in any real and living economy every actor is always entrepreneur." He also distinguishes capitalists, who offer capital for production, and entrepreneurs, who decide what to produce and actually initiate production and marketing. But von Mises remarks that, in the real world, lenders also necessarily are entrepreneurs because each loan comes with a risk of non-repayment. In the face of this uncertainty, in every act of lending, there is an element of an entrepreneurial venture (Mises, 1949). Von Mises presents two entrepreneurial types: (1) the "acting man in regard to the changes occurring in the data of the market;" and (2) the promoter who "refers to a datum that is a general characteristic of human nature." Another entrepreneurial trait according to von Mises are venturesomeness and a "quicker eye than a crowd." (Mises, 1966, p. 254, 255). In Mises's own words (1949/1966, p. 256) "entrepreneur is always a speculator. He deals with uncertainty conditions in the future. His success or failure depends on the correctness of his anticipation of uncertain events."

Hayek did not develop a theory of the entrepreneur per se (Klein, 2007). He used the term entrepreneur in several papers, in which he simply means businessman, without clearly distinguishing among entrepreneurs, managers, and other business profes- 
sionals. Horvitz (2007) holds that Hayek (1949, p. 196) anticipated Kirzner because Hayek introduced the not only the notion of "entrepreneur" but also "discovery."

Schumpeter distinguished two types of business-owners: contractors-performers and destructors. Only the latter can be regarded as entrepreneurs (Noga, 2009). They use a new combination of means of production through:

- Introduction of a new product or service;

- Application of a new method of production or sale;

- Opening a new market for the products or services already known;

- Reaching new sources of raw materials or semi-finished products;

- Application of new organizational form within sectors (Glapiński, 2012; Filion, 2008; McDaniel, 2005).

Baumol (1993) follows Schumpeter's characteristics of entrepreneurship in a very similar way (qtd. in Piecuch, 2010) and adding "new combination resulted from innovations." Formaini (2001) explains that: "Schumpeter was specific in arguing that the entrepreneur doesn't invent things, but exploits in novel ways what has already been invented. In combining existing inventions, the entrepreneur triggers creative destruction and brings into being new industries even as old ones are sometimes destroyed." Baumol claims that economic theories neglect entrepreneurship while, in his opinion, it should be the main subject of the economic analysis, as the "entrepreneurial function is a vital component in the process of growth of output and productivity" (Baumol, 1993). Baumol distinguishes the managerial and entrepreneurial roles and stresses that the entrepreneur is thereby assigned a heavy responsibility for the vitality of the free enterprise society (1993). After studying the diversity of entrepreneurship, Baumol introduces the term "hybrid entrepreneurs" (1990) for those who combine dependent and independent jobs. He also suggests (1990) that supply of entrepreneurs varies among societies and entrepreneurial activities differ because of their allocation between productive activities like innovation and largely unproductive like rent-seeking, tax avoidance, or shadow activities. Baumol argues that entrepreneurs' fundamental motivation is money, and they will earn with whatever means they have, not always ethically.

Schumpeterians distinguish between "replicative" entrepreneurs, who form small businesses much like other small businesses, and "innovative" entrepreneurs, who upset, disorganize, and disrupt the existing way of doing things. In the light of this research, the authors argue that replicative businessmen are not entrepreneurs, although they may be self-employed. 
Considering entrepreneurial behavior, Drucker also appears as Schumpeter's follower. Like his predecessor, Drucker perceives innovation, resources, and entrepreneurial behavior to be the keys elements of entrepreneurship (Drucker, 1985). According to him, not all business owners are entrepreneurs. Those who are, change or transmute values. Another of Drucker's important comments is that an enterprise does not even have to be small or new to be entrepreneurial; it is not only confined to economic institutions like modern universities or hospitals, or even capitalism. Drucker agrees that innovations give unproductive resources new opportunities for creating prosperity and economic growth. He believes that entrepreneurs' investment in innovation, if done properly, is not risky after all. In short, Drucker's idea of entrepreneurship has three characteristics: (1) to set in motion new products and services, (2) to organize production process in innovative ways to make a profit, and (3) to invest capital in order to achieve maximum benefits. Markedly, the infusions of venture capital do not necessarily foster entrepreneurship. Drucker declares that entrepreneurship is not "magical" or "mysterious." In his opinion, it is a discipline and, like any discipline, it can be learned. To this statement, Kuratko (2016) adds that "like all disciplines, entrepreneurship has models, processes and case studies."

Kirzner's theory of entrepreneurship is known as the theory of entrepreneurial alertness and discovery. Kirzner concentrates on alertness as entrepreneur's ability to perceive new economic opportunities that no prior economic actor has yet recognized. In his model, the fundamental quality of the entrepreneur is the ability to foresee demand for a new product that has not hitherto been manufactured. "Alertness refers to a sense of what might be "around the corner," it is "the sense to notice that which has hitherto not been suspected of existing at all" (Kirzner, 2008). In Kirzner opinion, entrepreneurial alertness is more characteristic than innovation. The former feature also means recognizing that certain factors of production are underpriced what may lead the entrepreneur to use this knowledge to make a profit. In Kirzner theory, we find two other characteristics of entrepreneurship: "spontaneous learning" and "entrepreneurial discovery" (Rocha, 2012; Churchill and Levis, 1983). According to Kirzner, alertness and learning by discovery are praxeological dimensions of entrepreneurship; that is, the study of those aspects of human action that one can grasp a priori. Kirzner also authored the term pure entrepreneur who performs the discovery function independently from ownership and investment (Klein, 2007). Moreover, what is interesting is Kirzner's observation about the relation between alertness and creativity: "creativity is much more than alertness. But the creativity that drives profit winning entrepreneurial behavior is a creativity that embraces alertness too - alertness to present and future price patterns, alertness to new technological possibilities, and alertness to possible future patterns of demand" (Kirzner, 2008, p. 11). He describes entrepre- 
neurship as an intangible asset without a direct link between the quantity of entrepreneurship and the amount of profit (Piecuch, 2010) To summarize, Kirzner's theory proposes the following main characteristics of entrepreneurship: (1) alertness, (2) the ability to achieve extraordinary profits and (3) gain competitive advantage over others.

According to Veblen (1999), the function of the entrepreneur "is held to be the coordinating of industrial processes with a view to the economics of production and heightened serviceability (...) He is moved by ideals of serviceability and an aspiration to make the way of life easier for his fellows (...) He has something of the instinct of workmanship." To Veblen, entrepreneurship is the subject of evolution from the pure form as the leader of the industry to financial entrepreneurship as the investor of capital (Griffin and Karayiannis, 2002; Parker 2009). Rothbard (1962) introduced another term - the capitalist-entrepreneur - a person who combines the ownership of capital with the entrepreneurial initiative.

M. Weber's idea was to leave aside the religion as the major drive of entrepreneurship and that the right combination of discipline and an adventurous free-spirit define the successful entrepreneur. The main entrepreneurial features according to Weber (1985) are: (1) the spirit of capitalism, (2) Protestant ethic, (3) adventurous spirit, and (4) the inducement of profit.

Leibenstein (1968) considers entrepreneurs to be gap-fillers, and he distinguishes routine entrepreneurship in well-defined markets and N-entrepreneurship. Leibenstein proposes the following characteristics of entrepreneurship: (1) recognition of market trends and gaps, (2) search for market niches, failures, and deficiencies, (3) introduction of profitable business to fill market gaps. Leibenstein (Casson 2003) regards entrepreneurship as a creative response to x-efficiency; a competitive threat to an inefficient organization.

The above overview of entrepreneurial theories and ideas concentrated on the distinguishing facets of entrepreneurship. In Table 1, the authors compare these entrepreneurial concepts and definitions with the forms of self-employment.

\section{Definitions of Entrepreneurship and Entrepreneur: Literature Review}

There exists considerable confusion in the way people use the term "entrepreneurship" (Ahmad and Seymour, 2008; Glinka and Gudkowa, 2011; Starnawska, 2011; Chmielecki and Sułkowski, 2016) as there is no single universally-agreed definition of entrepre- 
neurship (Davidsson, 2005; Gartner, 1988). Even OECD contributes to the confusion because each of its studies about this phenomenon presents a different definition (Ahmad and Seymour, 2008). Relevant literature abounds with competing definitions of entrepreneurship: "which differ along a number of dimensions, i.e. whether entrepreneurship should be defined in terms of dispositions, behavior, or outcomes; whether it belongs in the economic-commercial domain or can also be exercised in not-for-profit contexts; whether it belongs only in small and/or owner-managed firms or in any organizational context, and whether purpose, growth, risk, innovation or success are necessary criteria for something to qualify as entrepreneurship" (Davidsson, 2003). Moreover, several reviews of entrepreneurship definitions appeared in the existing literature (e.g. Cuervo, Ribeiro and Roig, 2007; Bengtsson and Peterson, 2008; Piecuch, 2010; Wach, 2015). These require regular updates, as there constantly appear new definitions along with the new developments in economy.

While preparing the comparative analysis Table 1, the authors have arbitrarily selected only these definitions that include features specific to the phenomenon of entrepreneurship. According to Venkataraman (1997), entrepreneurship involves the nexus of two phenomena: the presence of lucrative opportunities and enterprising individuals. Gartner (1988) remarks that it is incomplete to define entrepreneurship only in terms of one of these phenomena (Shane and Venkataraman, 2000). For example, if we only devise entrepreneurship from the characteristic of entrepreneur - understood as a person who establishes a new organization (which is, by the way, an unjustified limitation) - we omit the quality of opportunities that one has. In turn, should we only explain entrepreneurship by opportunities that appear, we lose sight of any cause that arises from individual abilities and skills of an entrepreneur.

The Global Entrepreneurship Monitor (GEM) operationalizes the concept of entrepreneurship as "any attempt at new business or new venture creation, such as self-employment, a new business organization, or the expansion of an existing business, by an individual, a team of individuals, or an established business." The level of entrepreneurship in GEM includes both the entrepreneurial activities to register new business entities and the entrepreneurial activities in existing organizations (GEM 2015/2016).

Reich (1987) considers leadership, management ability, and team-building to be the essential qualities of an entrepreneur, although they seem more like the characteristics of a manager. Filion (2008) notes that the definition of the entrepreneur will obviously differ depending on the author's paradigm. He presented the following six components that should be included in the entrepreneur definition: (1) innovation, (2) opportunity recognition, (3) risk management, (4) action, (5) the use of resources, and (6) added value. 
According to Ahmad and Seymour (2008), entrepreneurs are those (business owners) who seek to generate value through the creation or expansion of economic activity by identifying and exploiting new products, processes, or markets.

Shane (2003) and Timmons (1990; 2007) remind that entrepreneurs are the people able to see and act on previously unnoticed profit opportunities. This concept differs from Schumpeterian entrepreneurs by showing that they entrepreneurs depend less on knowledge creation and more on the existing information processing which presently seems to be the crucial ability for anyone who works in business.

Krueger and Brazeal (1994) link the entrepreneurs who want to run own business with those who believe in their own skills and good business opportunities. Since there is no possibility to separate business from entrepreneurial intentions, Krueger and Brazeal preclude the existence of "non-entrepreneurs:" business people without an entrepreneurial inclination.

Mühlböck et al. (2017) disagree with such approach. They believe that businesses develop not only thanks to people with entrepreneurial intentions, who recognize opportunities, but also by people who were forced to run a business. Mühlböck et al. include necessity as an additional antecedent of motivation to become an entrepreneur and identify one more group: those who have "the feeling that there are no other options to (re-)enter the labor market than to become self-employed." This is a good example of confusing entrepreneurs with the self-employed.

Sauka (2008) cites Davidsson and Henrekson (2002) who claim that productive entrepreneurship is an "essential factor of the economic performance of a country." From this statement, one may conclude that there is also unproductive entrepreneurship. Hence, Kshetri (2014) remarks that access to market, finance (capital), research and development, and technology is inherent to entrepreneurship.

The Kauffman Foundation Report (2017) declares that the state of entrepreneurship is improving, across new firm creation, local small businesses, and growth companies; which supports the idea that entrepreneurship develops in different types of business.

Blanchflower, Oswald, and Stutzer (2001) along Davidsson (2003) characterize entrepreneurs as people who independently work on their own regardless of whether their economic activities are small or large. Moreover, Nooteboom (2002) and Shane (2003) highlight independence as the alluring factor of entrepreneurship and a goal in itself. 
Some call this striving for independence sometimes "the entrepreneurial spirit" or "the free spirit” (Schumpeter qtd. in Berlin, 2015).

Casson (2003) divided the approaches to entrepreneurs into two categories: functional and indicative. The former pinpoints what an entrepreneur does while the latter - the entrepreneurs' status, relationship with other parties, and position in society. Casson highlights that entrepreneurs are decision-makers who improvise solutions to problems that cannot be solved by routine alone. Gimenez-Roche (2011) describes entrepreneurial action as a tridimensional phenomenon which integrates profit-seeking, uncertainty-bearing and ultimate power of decision-making in the one person of the acting entrepreneur. Kreft and Sobel (2003) along Baumol (1990) foreground that economic freedom is a public policy that best fosters entrepreneurship, while Weigl (2008) and Bjerke (2007) argue that "non-material resources are basic in our modern entrepreneurial economy."

Propstmeier (2011) states that the knowledge of business positively influences the decision to become an entrepreneur but, surprisingly, has a "strong negative effect on the decision to become a freelancer." Klein (2010) expands the classical concept of the entrepreneur as a judgmental decision-maker by linking the capitalist-investor and the entrepreneur-promoter. Klein explains that by exploring the components of entrepreneurial mindset, one can exactly understand who is an entrepreneur (2010). Here, the question arises: How to know what is an entrepreneurial mindset and what it really means? Etzioni (1987, p. 177-178) stresses the specific type of adaptation that entrepreneurs have to pass: "[it is an] adaptation achieved by the accumulation of small adjustment." The peculiarity of the entrepreneurial adaptation is that entrepreneurs are "far from being 'adapted' to the constantly changing environment at all times." In other words, should they only adapt to the existing situation, they can be neither destructors nor revolutionaries in their fields of interest. This is because adaptation is usually evolutionary. Nevertheless, this insight does not conflict with the observation that adapting to changes is important to entrepreneurs (Simon et al., 2002). Robinson et al. (2006) note that "entrepreneurship may be seen as one type of leadership orientation, namely that of leading a business venture." Silberzahn (2013, p. 16) emphasizes the importance of entrepreneurial commitment to their ventures, especially in the nascent markets, and that "understanding the role of commitment can also enrich the novelty and strategic variety of the entrepreneur's repertoire in dealing with uncertainty." In a sense, commitment also means patience. As Swinscoe (2013) outstandingly remarks, there is a special need for the "patience for the impatient," as most entrepreneurs are impatient in the drive to achieve their goals. Patience, persistence, and perseverance are important in entrepreneurial activities. They are nevertheless abilities which can be learned. Also to Blankenship (2017) patience seems the 
distinguishing characteristic of entrepreneurs. One cannot put it better than Steve Jobs did: "I'm convinced that about half of what separates successful entrepreneurs from the non-successful ones is pure perseverance" (in Baron, 2012, p. 86).

Hebert and Link (1989) observe that "the entrepreneur is someone who specializes in taking responsibility for and making judgmental decisions that affect the location, form, and the use of goods, resources or institutions." Meadows (2016) dedicates his entire book to self-discipline as the crucial entrepreneurial trait.

While this article deals not with the psychology of entrepreneurs, two purely psychological traits need special mention here, as they often influence other entrepreneurial activities. They are overconfidence (Busenitz, 1999) and overoptimism (Meza and Southey, 1996).

Last but not least, we should remember about the fairly new idea of networking (Weigl 2008; Gurrieri, 2013), which today appears as one of the most crucial skills any entrepreneur can have. What is new is the fact that interactions, relations with customers, collaborators, or suppliers often develop via the Internet. It makes contemporary business connections easier and quicker. However, social networking was always the lifeblood of entrepreneurship, critical to business development. Only the tools changed

The above overview of entrepreneurial theories, ideas, and definitions identifies these facets of entrepreneurship that distinguish it from other types of business activities. Table 1 presents the most popular definitions and characteristics of entrepreneurship in the reviewed literature.

\section{Self-Employment: Substance and Categories}

The self-employed group is heterogeneous because it gathers various activities. A farmer may be self-employed just like a lawyer with individual practice, a medical doctor, an online computer graphic designer, a small shop owner, a one-person business hairdresser, and somebody who manufactures bead jewelry and sells it among friends and acquaintances.

The affiliation with the self-employed group often depends on the legal regulations in a country. Many regulations often define the self-employed as people who have officially registered individual business activity and do not employ others. But such formal definition does not cover other possibilities, a whole range of legal activities 
which naturally emerge from self-employment. The self-employed can work under different labor contracts such as contract of mandate, contract of specific work, management contract, or contract of representation. Because of the quantity and diversity of the self-employed and self-employment definitions, on the one hand, the official statistics do not reflect all self-employment forms and, on the other, they use the activities which are not universally treated as self-employment. Based on our literature review from 2017, we identify the following criteria that distinguish the self-employed:

- the level of independence and autonomy in the workplace:

- completely independent self-employed who work for the customers of their own choice, when they want, often also how and where they want, without any formal supervision, and

- dependent self-employed, who work exclusively for one employer and are dependent only on him/her, who work under supervision, without taking individual economic risk, usually in the place and time indicated by the employer.

- the motivation to become self-employed (pull and push factors):

- voluntary self-employed means the people that have selected such way of work because they themselves wanted, and

- necessity self-employed means the people who work this way because they were forced to do so. The reason here is either the labor market situation, lack of options or satisfactory jobs, or employer's pressure on self-employment (sine qua non employment condition).

- the capacity to invest own capital:

- those who invest their own capital and other resources and take full financial consequences of this investment, and

- those who do not invest their own capital or who have co-investors and for this reason do not risk as much when starting the new business.

- innovativeness/creativity:

- innovators-destructors who implement new ideas to their business, and

- replicative businessmen (copycats) who copy the existing business models, products, and services.

- the level of professionalism (professional merit):

- self-employed with a high level of education, high-skilled professionals (individual professionals: ipros), and

- self-employed with a lower level of education, unskilled, with limited abilities for which they have a low position in the labor market and low employability.

- the social and financial outcome: 
- social and financial winners satisfied with their situation in both these aspects (successful people), and

- social and financial losers for whom self-employment was a necessity and who are not satisfied with their occupational and financial situation.

With the abovementioned criteria in mind, we propose the following self-employed groups:

- Dependent self-employed: people who often work under or provide services to one employer within the legal framework of civil or commercial law, but who actually depend on and usually integrate into the company for which they work. Most call this type of self-employment bogus, false, fake, or quasi because it usually works the same way as with the ordinary employees employed under permanent contracts regulated by the labor law. For employers, such employment form generally aims at tax and other contributions optimization. In many cases, although not always, it is the only possibility of employment forced on the market by the employers. Dependent self-employed generally are neither risk-takers nor investors. Usually, they are not particularly creative or innovative. Therefore, this group may be considered rather as part of conventional employment (wage employees) but not as pure entrepreneurs;

- Hybrid self-employed ("part-time" self-employed): those who have a stable, permanent employment contract with one employer but can work with other employers under contracts regulated by the Civil or Commercial Code. Hybrid self-employed can be either innovative or replicative. In fact, they may be part of the other self-employed groups:

- dependent self-employed, when they provide additional work to one client only and perform it under similar conditions as hired employees;

- one-person innovative start-up owners, when they start their venture independently of simultaneous work for the main employer;

- one-person, replicative business owners, when they connect a stable permanent job with other activities; for instance, after hours online handicraft sale;

- independent professionals when they provide services for other contractors after hours.

- One-person , replicative business owners: owners of small shops, restaurants, service points, or simple production, who usually work without permanent employees. Most consider this kind of self-employment to be entrepreneurial regardless whether one employs others or not. In the Schumpeterian view, small business owners are replicative businessmen who do not invent anything new, but rather duplicate the existing business models, solutions, products, or 
services; and such activities do not correspond with the typical understanding of entrepreneurship;

- One-person innovative start-up owners in Schumpeter's view, they innovate when they introduce a new product or service, apply a new method of production or sale, open a new market for the products or services already known, gain new sources of raw materials or semi-finished products, and apply new organizational form in a sector. The authors' analysis shows that each self-employed innovative start-up owner has all the main characteristics of an entrepreneur;

- Freelancers (independent professionals freelancers, ipros, independent contractors, opportunity self-employed): a group that consists of people with the highest qualifications and skills who are increasingly in demand in today's labor market. They usually do not invest their own financial capital because their competences form their intellectual capital. Usually, they are independent and work in projects with different companies. They can temporarily work in teams but also as lone wolves;

It should now be clear that the nature of the self-employed groups, their activities, and other characteristics may greatly differ.

\section{Entrepreneurship and Self-Employment: Comparative Theoretical Analysis}

The discussion continues whether entrepreneurship is a transitional economic function or a specific labor market category denoting all the self-employed. Both in academic disputes and practical solutions in politics or statistics one encounters mostly arbitrary decisions.

For Perulli (2003), the main criterion that distinguishes entrepreneurial activity from self-employment is the way in which they organize work and the means of production. If the economic activity develops without an organizational base, it means self-employment and not entrepreneurship. Inevitably, there arises the problem of voluntary and enforced self-employment; in other words, entrepreneur's motivation. At the surface, it may seem that the voluntarily self-employed are more entrepreneurial than the forcedly self-employed. The former usually cannot rely on others, are self-dependent, and dive deep into business. In such situation, the entrepreneurial skills are a must - especially for those who want to survive on the competitive market - while the forcedly self-employed often lack them. 
The dispute about the entrepreneurship of "opportunity" and "necessity" often emerges, when it actually, in our opinion, concerns self-employment. Williams and Williams (2011) state that this common dichotomy of entrepreneurs, as they say, motivations is misleading. They conclude that motivations of entrepreneurs change over time because their drive frequently is both necessity and opportunity. Block and Sandner (2009) find that opportunity entrepreneurs remain in self-employment significantly longer than necessity entrepreneurs. Although there is not enough strong empirical evidence, one may assume that those initially forced into self-employment also demonstrate entrepreneurial skills: forced self-employment may simultaneously be their own choice, preference, and risk. Even when the self-employed decides for dependence with the intention to only shortly appear in the labor market and only for utilitarian reasons - to accrue financial resources to set up a new business or pay less mandatory contributions in the first years of the business' existence - this still confirms their own kind of entrepreneurial skills. However, the self-employed may run a business and not be entrepreneurial. In other words, while self-employed often receive the title of entrepreneurs, not all entrepreneurs are self-employed and not all self-employed are entrepreneurial. This general observation indicates that it is unjustified to use both terms as exact synonyms. Undoubtedly, the self-employed and entrepreneurs have some things in common; both groups are heterogeneous in age, gender, education, field of business, or founding sources; but it does not mean we should perceive them as equal.

Some scholars (Shane, 2008; Cieślik, 2015; 2016) argue that entrepreneurship comes with risk-bearing, which happens when the entrepreneur engages significant financial or other assets and employs people. In the case of failure, business closing costs like the settlement of liabilities to creditors, including employees, can be substantial. If that is an entrepreneurship concept, then it means that some sort of organization has to be created which, in turn, means that the risk is not borne by a one-person business with minimal involvement of his/her own funds. Similar opinion present, for example, Amit, Glosten, and Mueller (1993) or Shane and Venkataraman (2000): "Entrepreneurship can also occur within an existing organization. Moreover, opportunities can be sold to other individuals or to existing organizations." Shane and Venkataraman believe that entrepreneurship does not require a green field organization, but they do not exclude such option.

All these discussions show that entrepreneurs may appear among different types of self-employed but not, as Cantillon wants, among all of them (Casson, 2003). It is debatable to treat a one-person business as non-entrepreneurial because of small risk in comparison with larger organizations. Certainly, the "just me" self-employed people 
do bear a risk that - for them - can be substantial. Thus, keeping in mind the risk factor, without doubt, small and solo businessmen can also be entrepreneurs. The failure of a venture is tightly related to risk and uncertainty, which can also be their fate.

Thaler (2015, p. 351-352) observes that losses loom larger than gains to most people - not distinguishing small and big entrepreneurs when it comes to failure, which, in his opinion, "happens at least half if not more of the time." He calls for the state to prepare "a softer cushion for failure" for all entrepreneurs and remarks that we must find ways to mitigate the costs of failures. The latter could be more effective in stimulating new business start-ups than cutting taxation for those who earn much more than $97 \%$ of US small entrepreneurs.

What is interesting is the idea of distinguishing "pure" entrepreneurs from others. According to Folta et al. (2010, p. 3), the former are outnumbered by individuals who mix self-employment and wage work, that is by hybrid self-employed. These authors argue that a lack of self-employment experience leads to a preference for hybridity, particularly useful for highly capable individuals who lack entrepreneurial experience (Folta et al., 2010, p. 28; cf. Baumol, 1990, p. 6).

Table 1 shows the results of our study on self-employment and entrepreneurship. One must nevertheless bear in mind that the entrepreneurs' characteristics intentionally exclude several important features. The authors only concentrated on economic and sociological approaches to the matter. The psychological context, especially entrepreneurs' motivation, deserves a separate article. The authors also excluded significant demographic factors: gender, age, the level of education attainment, ethnicity; as well as contextual factors like regulatory frameworks, taxes, regulations, and other public rules and institutions that affect businesses. On the one hand, this is an obvious limitation of this research; on the other, this arbitrary restraint allows the authors to compare selected, mostly economic aspects of entrepreneurship and self-employment, thus bringing a structure into the otherwise chaotic presence of both terms. 


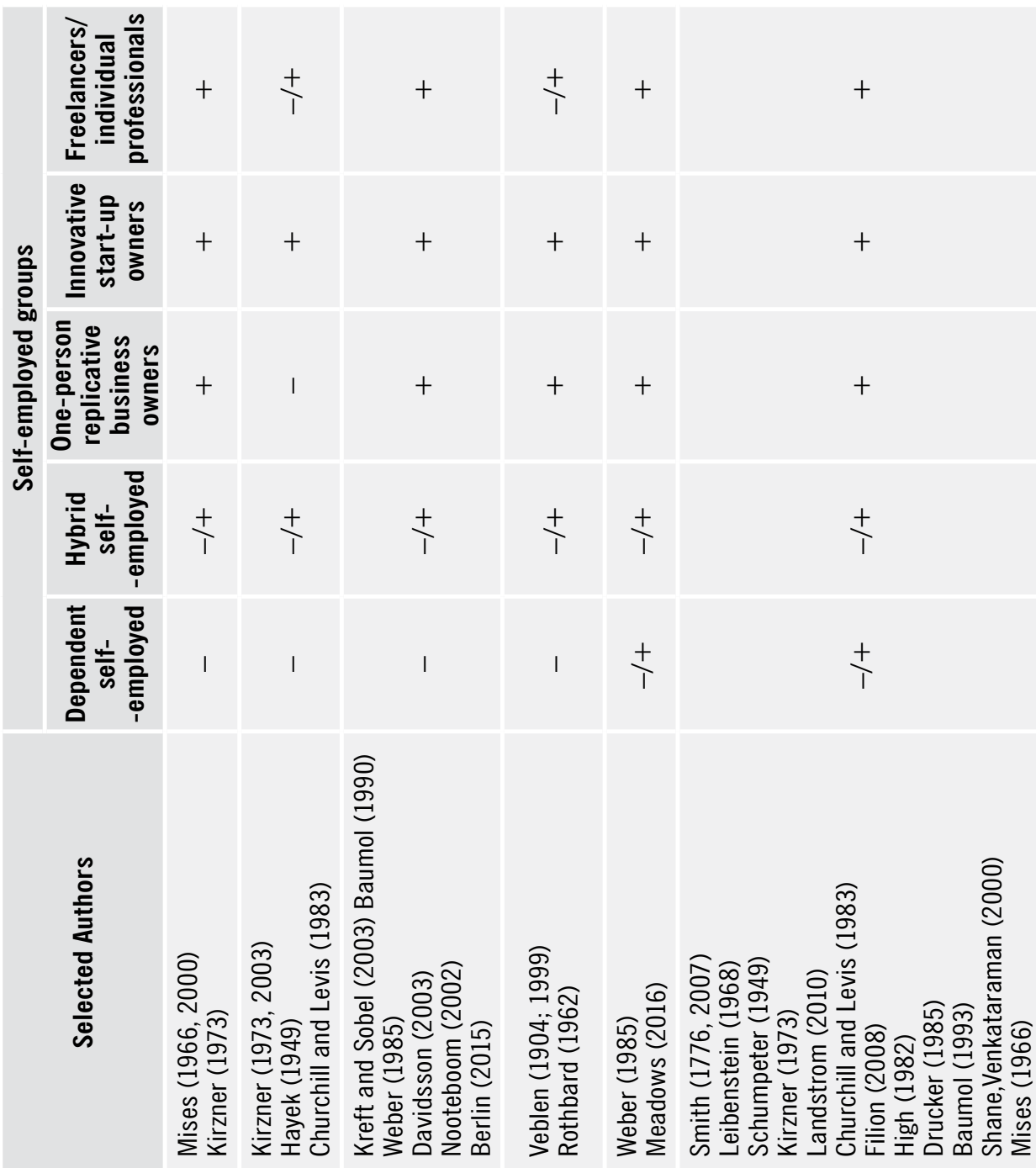

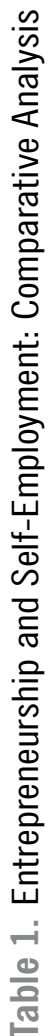

\begin{tabular}{|c|c|c|c|c|c|c|}
\hline 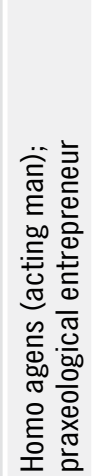 & 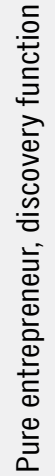 & 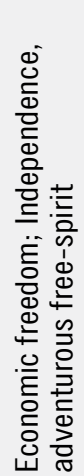 & 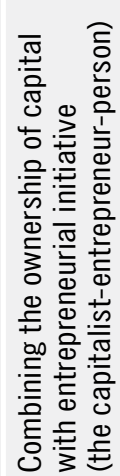 & 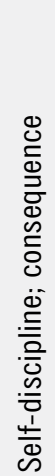 & 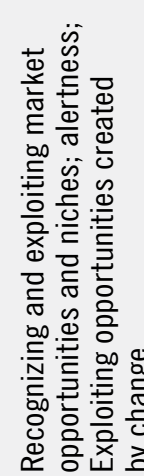 & 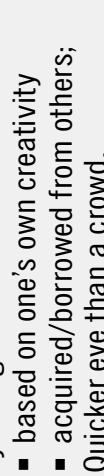 \\
\hline
\end{tabular}




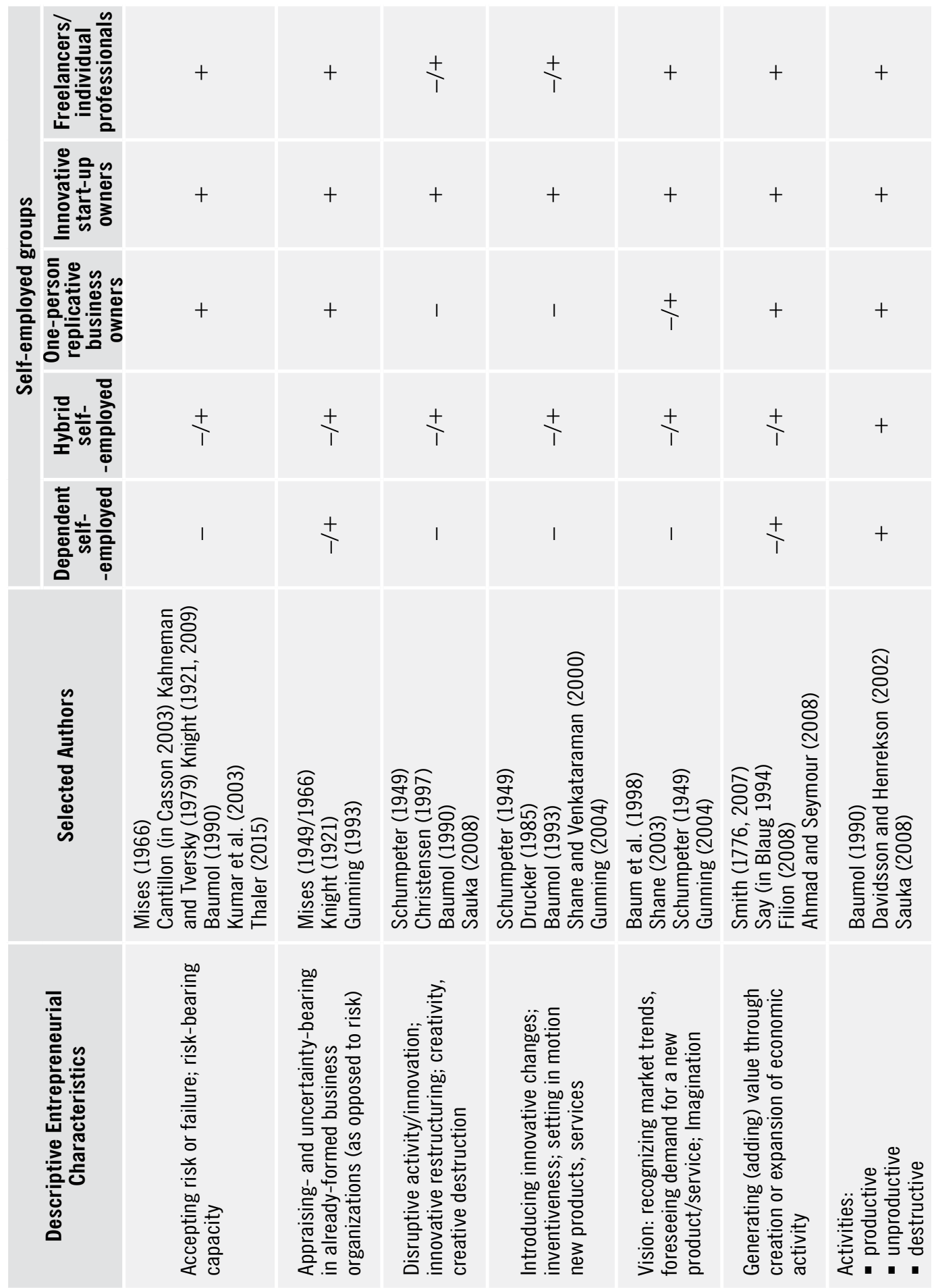




\begin{tabular}{|l|l|l|l|l|l|l|l|l|l|}
\hline & + & + & + & + & + & + & + & + & + \\
\hline
\end{tabular}
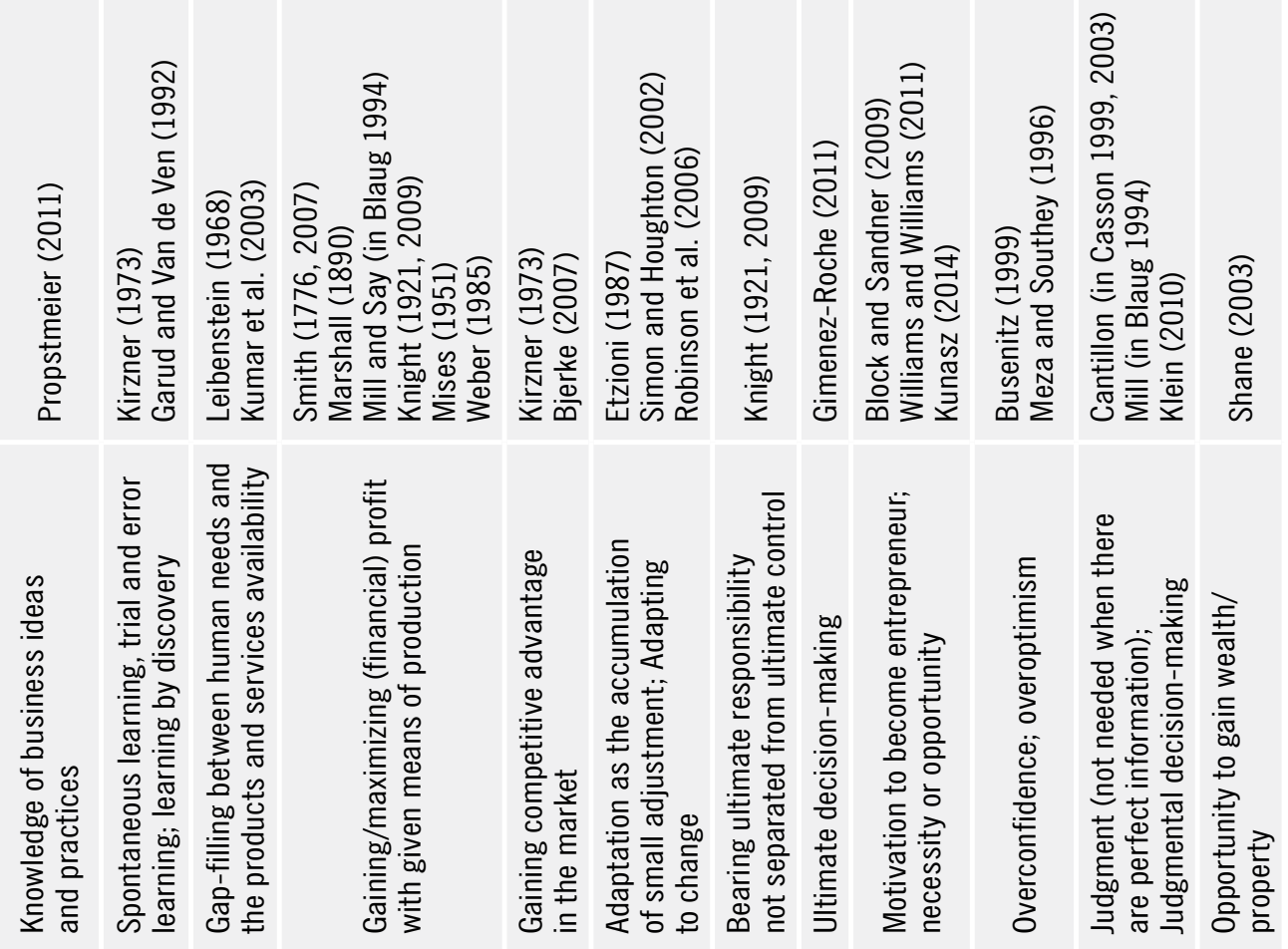


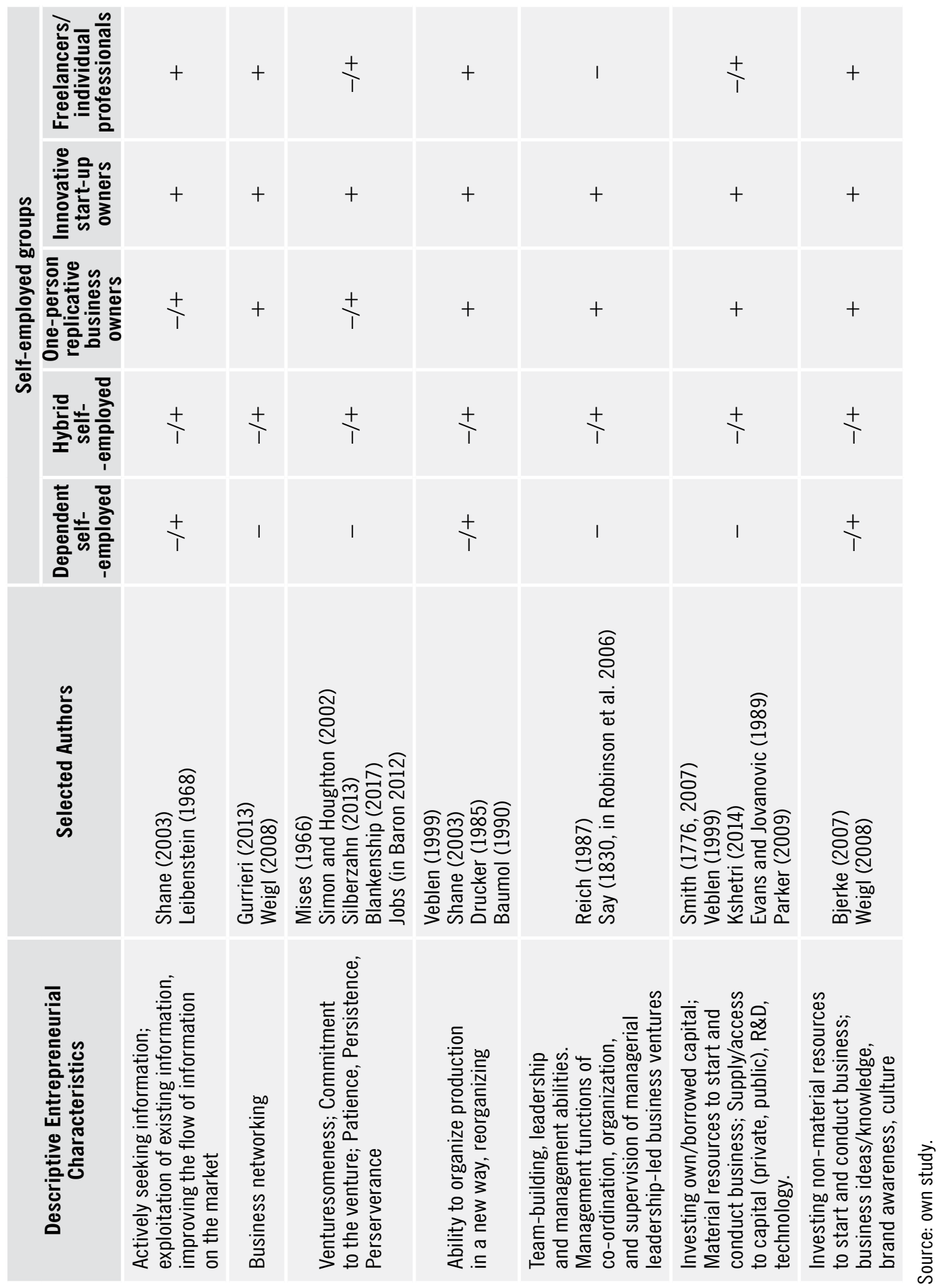




\section{Discussion of Results}

The analysis supports the opinion that there is no generally accepted definition of neither the "entrepreneurship" nor "self-employment." Each receives different characteristics based on various core meanings that derive from several scientific disciplines. Thus, comparative analysis of self-employment and entrepreneurship must accept what is clearly indicated in Table 1, that groups of self-employed greatly vary in merit and method of operation. Following the characteristics in Table 1, the authors distinguish the self-employed groups below. They differentiate on the basis of proximity to and the number of entrepreneurial traits.

Table 2. Groups of self-employed and the number of entrepreneurial traits

\begin{tabular}{|c|c|c|c|c|c|}
\hline $\begin{array}{c}\text { Entrepreneurial } \\
\text { characteristic } \\
\text { (+) applies }\end{array}$ & $\begin{array}{c}\text { Dependent } \\
\text { self-employed }\end{array}$ & $\begin{array}{c}\text { Hybrid } \\
\text { self-employed }\end{array}$ & $\begin{array}{c}\text { One-person } \\
\text { business } \\
\text { owners }\end{array}$ & $\begin{array}{c}\text { One-person } \\
\text { innovative } \\
\text { start-up } \\
\text { owners }\end{array}$ & $\begin{array}{c}\text { Freelancers / } \\
\text { individual } \\
\text { professionals }\end{array}$ \\
\hline- & 17 & 1 & 3 & 1 & 1 \\
\hline$-/+$ & 13 & 29 & 8 & 0 & 13 \\
\hline+ & 3 & 3 & 22 & 32 & 19 \\
\hline
\end{tabular}

Source: own study.

Self-employment is so diverse that the analysis of the labor market with the use of the general terms and statistics seems inefficient. The authors, thus, propose that future research treats each of the above groups separately.

\section{Conclusion}

Entrepreneurship receives descriptions from many scientific positions and still gathers doubt because there is no uniform understanding of what it is and how it can be assessed. No coherent and universal definition appeared yet, while relevant literature abounds in competing terms. Entrepreneurship is yet to receive a coherent theory and answers to the most basic questions such as its role in the economic growth. The above study makes the authors share Baumol's opinion that - although entrepreneurship drives the economy - mainstream economic theories mostly neglected it. These reservations also apply - and perhaps even more - to self-employment, which also lacks a universally accepted definition and theory. Scholars and practitioners never reached 
a consensus about the nature of self-employment. Some perceive it as a kind of entrepreneurship, while others as a type of hired labor naturally present in the contemporary labor market. Yet other researchers simply and unjustly equate entrepreneurship with self-employment.

These inconsistencies led the authors of this paper to select the criteria that predominantly characterize entrepreneurship, from the economic viewpoint, and confront them with the main forms of self-employment. The aim of this paper was to position self-employment in the entrepreneurship paradigm. The overview of entrepreneurial theories, definitions, and ideas in relevant literature identified the facets that distinguish entrepreneurship from other types of business activities. The comparison of selected entrepreneurial characteristics with the categories of self-employed vitally supported this study. As a result, Table 1 offers a helpful audit tool for examining existing definitions and theories of these two concepts; as well as for the future empirical studies of both. The authors believe in the practical application of Table 1; for example, when tax or social security systems require adjustments to the changes in the labor market.

\section{Research Limitations}

Some papers closely link the theory of entrepreneurship to the theory of group behavior (Mosakowski, 1998; Cook and Plunkett, 2006). It entails a psychological and sociological perspective. The above study considers only a few approaches related to these disciplines, examining only the literature that concerns the different types of self-employment and selected entrepreneurial characteristics that originate from economic theories. The authors realize that it is inevitable to also refer to other selected scientific disciplines because the approach to both self-employment and entrepreneurship should be interdisciplinary. Hence the appearance of some psychological and behavioral aspects of entrepreneurship and self-employment. However, the length of the paper precluded a thorough overview of sociological and psychological theories - not to mention cultural and anthropological - which leaves ample space for development in future studies.

\section{Summary}

(1) Scholars and practitioners use "entrepreneurship" and "self-employment" in different contexts with divergent understanding and definitions. A plethora of these concepts and their characteristics is most interesting for those who 
study both from a theoretical viewpoint but simultaneously forms a bottleneck, which we must remove when aiming to perform reliable empirical comparative studies.

(2) This study shows that the self-employed group is so diverse that we should not treat it as a single unit but, instead, must become the target of socio-economic analyses as a whole. Moreover, the discussion about the participation of the self-employed in entrepreneurship should concern particular groups of self-employed and specifically defined perspectives.

(3) Self-employment has gradually gained importance in today's global labor markets, raising interest in the entrepreneurial side of this form of employment. Table 1 shows which entrepreneurial characteristics apply to which forms of self-employment. This comparison supports the claim that "self-employment" and "entrepreneurship" are not one and the same notion. Not all kind of self-employed are entrepreneurs, and not all entrepreneurs have to be self-employed. This fact has been acknowledged by the OECD (2011): "self-employed can be running business but not be entrepreneurial," but it is not a universal approach by far. In the opinion of the authors of this paper, the time has come to use harmonized definitions of self-employment and entrepreneurship at least in official European statistics and papers. Here we must mention Davidsson's (2005) belief that the concepts concerning entrepreneurial characteristics come from widely differing backgrounds, which precludes the profiling of a typical entrepreneur. Although Table 1 summarizes most of the entrepreneurial characteristics from selected theories, the list remains open for future studies.

\section{References}

Ahmad, N. and Seymour, R.G. (2008). Defining Entrepreneurial Activity. Definitions Supporting Frameworks for Data Collection. OECD Statistics Working Papers 2008/01. Paris: OECD, https://doi.org/10.1787/243164686763

Amit, R., Glosten, L. and Mueller, E. (1993). Challenges to theory development in entrepreneurship research. Journal of Management Studies, 30: 815-834, https://doi.org/10.1111/j.1467-6486.1993.tb00327.x

Audretsch, D., Callejon, M. and Aranguren, J. (2008). Entrepreneurship, Small Firms and Self-employment. In: M.D. Parrilli, P. Bianchi and R. Sugden (eds.), High Technology, Productivity and Networks-A Systemic Approach to SME Develop, https://doi.org/10.1057/9780230583726_6

Baron, R.A. (2012). Entrepreneurship: An Evidence-based Guide. Edward Elgar Publishing.

Baum, J.R., Locke, E.A. and Kirkpatrick, S. (1998). A longitudinal study of the relation of vision and vision communication in venture growth in entrepreneurial firms. Journal of Applied Psychology, 83(1): 45-54, https://doi.org/10.1037/0021-9010.83.1.43

Baumol, W.J. (1993). Entrepreneurship, management, and the structure of payoffs. Cambridge, Mass.: MIT Press. 
Baumol, W.J. (1990), Entrepreneurship: Productive, Unproductive, and Destructive. Journal of Political Economy, 98(5): 893-921.

Baumol, W.J. (1968), Entrepreneurship in Economic Theory. The American Economic Review, 58(2): 64-71, https://ssrn.com/abstract=1506344

Bengtsson, N. and Peterson, K. (2008). What are they talking about when they talk about entrepreneurship? Jönköping University, https://www.diva-portal.org/smash/get/diva2:3593/FULLTEXT01. pdf (11.09.2017).

Berlin, N.A. (2015). Animal Spirits Driving Economic Change: Empirical Evidence from Entrepreneurs. Campus Verlag.

Bjerke, B. (2007). Understanding Entrepreneurship. Edward Elgar Publishing.

Blanchflower, D., Oswald, A.J. and Stutzer, A. (2001). Latent entrepreneurship across nations. European Economic Review, 45 (4-6): 680-691, https://doi.org/10.1016/S0014-2921(01)00137-4

Blankenship, M. (2017). 8 Successful People Who Proved Persistence Beats Perfection, https://www.success.com/article/8-successful-people-who-proved-persistence-beats-perfection (11.09.2017).

Blaug, M. (1994). Teoria ekonomii: Ujęcie retrospektywne. Warszawa: Wydawnictwo Naukowe PWN. Block, J. and Sandner, Ph. (2009). Necessity and Opportunity Entrepreneurs and Their Duration in Self-Employment: Evidence from German Micro Data. Journal of Industry, Competition and Trade, 9(2), https://doi.org/10.1007/s10842-007-0029-3

Brown, T.E. and Uljin, J.M. (2004). Innovation, Entrepreneurship and Culture. The Interaction between Technology, Progress and Economic Growth, Business and Economics. Edward Elgar Publ. Ltd., https://doi.org/10.4337/9781845420550

Busenitz, L.W. (1999). Entrepreneurial Risk and Strategic Decision Making. The Journal of Applied Behavioral Science, 35(3): 325-340.

Bygrave, W. and Hofer, C. (1991). Theorizing about Entrepreneurship. Baylor University, https://www.slideshare.net/namekuwanday/theorizing-about-entrepreneurship-45779199 (7.09.2017).

Casson, M.C. (1990) (ed.). Entrepreneurship. Vol. 13. International Library of Critical Writings in Economics.

Casson, M.C. (2003). The Entrepreneur: An Economic Theory. Edward Elgar Publ.

Casson, M.C. (1991). Entrepreneurship. In: The Concise Encyclopedia of Economics, online (26.09.2017).

Chmielecki, M. and Sułkowski, Ł. (2016). Metaphors of Entrepreneurship among Polish Students: Preliminary Research Findings. Entrepreneurial Business and Economics Review, 4(4): 141-151, http://dx.doi.org/10.15678/EBER.2016.040409

Christensen, C.M. (1997). The Innovator's Dilemma: When New Technologies Cause Great Firms to Fail. Boston, MA: Harvard Business School Press,

http://www.hbs.edu/faculty/Pages/item.aspx?num=46

Churchill, N. and Levis, V. (1983). The Five Stages of Small Business Growth. Harvard Business Review, May-June.

Cieślik, J. (2016). Czy samozatrudnieni to przedsiębiorcy, Rzeczpospolita, 12.12.2016, http://www.rp.pl/Opinie/312129888-Czy-samozatrudnieni-to-przedsiebiorcy.html\#ap-1

Cieślik, J. (2015). Capturing Statistically the "Intermediate Zone Between the Employee and Employer Firm Owner. International Review of Entrepreneurship, 13(3).

Congregado, E., Golpe, A.A. and Carmona, M. (2010). Is it a good policy to promote self-employment for job creation? Evidence from Spain. Journal of Policy Modeling, 32(6): 828-842,

https://doi.org/10.1016/j.jpolmod.2010.09.001 
Cook, M. and Plunkett, L.B. (2006). Collective Entrepreneurship An Emerging Phenomenon in Producer-Owned Organizations. Journal of Agricultural and Applied Economics, 38(2): 421-28, https://doi.org/10.1017/S1074070800022458

Cranford, C.J., Vosko, L.F. and Zukewich, N. (2003). Precarious employment in the Canadian labor market: A statistical portrait. Just Labor: A Canadian Journal of Work and Society, 3, Fall.

Cuervo, A., Ribeiro, D. and Roig, S. (2007). Entrepreneurship: Concepts, Theory and Perspective. Introduction. Berlin: Springer, https://doi.org/10.1007/978-3-540-48543-8

Cullen, J.B., Johnson, J.L. and Parboteeah, K.P. (2014). National rates of opportunity entrepreneurship activity: Insights from institutional anomie theory. Entrepreneurship Theory and Practice, 38(4): 775-806, https://doi.org/10.1111/etap.12018

Davidsson, P. (2003). The domain of entrepreneurship research: Some suggestions. In: J. Katz and D. Shepherd (eds.), Advances in entrepreneurship, firm emergence and growth. Elsevier, Oxford.

Davidsson, P. (2005). The types and contextual fit of entrepreneurial processes. International Journal of Entrepreneurship Education, 2(4), https://doi.org/10.1016/S1074-7540(03)06010-0

Davidsson, P. and Henrekson, M. (2002). Determinants of the prevalence of start-ups and high-growth firms. Small Business Economics, 19(2): 81-10, https://doi.org/10.1023/A:1016264116508

de Meza, D. and Southey, C. (1996). The Borrower's Curse: Optimism, Finance and Entrepreneurship. Economic Journal, Royal Economic Society, 106(435): 375-386, https://doi.org/10.2307/2235253

Demirgüç-Kunt, A., Klapper, L., Panos, G. (2007). The origins of self-employment. Development Research Group. Washington DC: World Bank.

Douglas, E.J. and Shepherd, D.A. (2000). Entrepreneurship as a utility maximizing response. Journal of Business Venturing, 15: 231-251, https://doi.org/10.1016/S0883-9026(98)00008-1

Drucker, P.F. (1985). Innovation and Entrepreneurship. New York: Harper and Row Publishers.

Eckhardt, F. and Eade, J. (eds.) (2011). The Ethnically Diverse City, Future Urban Research in Europe. BWV Verlag.

Elkjaer, J.R. (1991). The Entrepreneur in Economic Theory: An Example of the Development and Influence of a Concept. History of European Ideas, 13(6): 805-815, https://doi.org/10.1016/0191-6599(91)90143-M

Etzioni, A.(1987) Entrepreneurship, Adaptation and Legitimation. A Macro-Behavioral Perspective. Journal of Economic Behavior and Organization, 8(1987): 175-189, https://doi.org/10.1016/0167-2681(87)90002-3

EU SWD (2016). European Commission Proposal for a Directive of the European Parliament and the Council on the conditions of entry and residence of third-country nationals for the purposes of highly skilled employment and repealing Directive 2009/50/EC

https://ec.europa.eu/home-affairs/sites/homeaffairs/files/what-we-do/policies/european-agenda-migration/proposal-implementation-package/docs/20160607/directive_conditions_entry_residence_third-country_nationals_highly_skilled_employment_impact_assessment_part_1_ en.pdf $\overline{(31.10 .2017) .}$

Evans, D.S. and Jovanovic, B. (1989). An Estimated Model of Entrepreneurial Choice under Liquidity Constraints. Journal of Political Economy, 97: 111-119, https://doi.org/10.1086/261629

Filion, L.J. (2008). Defining the Entrepreneur. Complexity and Multi-Dimensional Systems. Some Reflections, HEC Montreal, Working Paper August, https://doi.org/10.4337/9781849808453.00011

Filion, L.J. (2011). Defining the entrepreneur. In: L.-P. Dana (eds.), World Encyclopedia of Entrepreneurship. Cheltenham, UK and Northampton, MA, USA: Edward Elgar.

Folta, T.B., Delmar, F. and Wennberg, K. (2010). Hybrid Entrepreneurship, IFN Working paper, No. 825.

Formaini, R.L. (2001). The Engine of Capitalist Process: Entrepreneurs in Economic Theory. Economic and Financial Review, Fourth Quarter: 2-11. 
Gartner, W.B. (1988). Who is the entrepreneur? is the wrong question. American Journal of Small Business, 12: 11-32, https://doi.org/10.1177/104225878801200401

Garud, R. and Van de Ven, A. (1992). An empirical evaluation of the internal corporate venturing process. Strategic Management Journal, 13: 93-109.

Gimenez-Roche, G.A. (2011). A Socially Situated Praxeological Approach to Entrepreneurship. The Journal of Entrepreneurship, 20(2): 159-187.

Glapinski, A. (2012). Schumpeterowska teoria przedsiębiorcy, czyli skąd się bierze pies. Konsumpcja i Rozwój, 1.

Glinka, B. and Gudkova, S. (2011). Przedsiębiorczość. Warszawa: Wolters Kluwer Polska.

Global Entrepreneurship Monitor (GEM). http://www.gemconsortium.org/report (18.02.2018).

Griffin, R. and Karayiannis, A.D. (2002), T. Veblen's Evolutionary Theory of Entrepreneurship. History of Economic Ideas, 10(2): 61-83.

Guerra, G. and Patuelli, R. (2016). The Role of Job Satisfaction in Transitions into Self-Employment. Entrepreneurship Theory and Practice, 40(3), https://doi.org/10.1111/etap.12133

Gunning, J. (1993). Entrepreneurists and Firmists: Knight vs. the Modern Theory of 4the Firm. Journal of the History of Economic Thought, 15 March: 31-53.

Gunning, J.P. (2004). Praxeological Entrepreneurship, November 8, http://www.constitution.org/pd/gunning/subjecti/workpape/cowen.pdf (15.10.2017), https://doi.org/10.1017/S1053837200005253

Gurrieri, A.R. (2013). Networking Entrepreneurs. The Journal of Socio-Economics, 47: 193-204, https://doi.org/10.1016/j.socec.2013.09.007

Hayek, F.A. (1949). The Intellectuals and Socialism. University of Chicago Law Review, 16(3), https://doi.org/10.2307/1597903

Henrekson, M. (2007). Entrepreneurship and Institutions, IFN Working Paper. No. 707, Research Institute of Industrial Economics.

Hebert, R.F. and Link, A. (1989). In Search of the Meaning of Entrepreneurship Small Business Economics, 1(1): 39-49.

High, J.C. (1982). Alertness and Judgement: Comment on Kirzner. In: I.M. Kirzner (ed.), Method, Process and Austrian Economics: Essays in Honor of Ludvig von Mises. Lexington, MA.

Horvitz, S. (2007). Klein on Hayek and Entrepreneurship. In: Fu-Lai T. Yu, D.S. Kwan (2016). Chinese Entrepreneurship: An Austrian Economics Perspective. London-New York: Routledge, Taylor and Francis.

Hughes, K.D. (2006). Exploring motivation and success among Canadian women entrepreneurs. Journal of Small Business and Entrepreneurship, 19(2): 107-120, https://doi.org/10.1080/08276331.2006.10593362.

Johansson, E. (2005). An Estimate of Self-Employment Income Underreporting in Finland. Nordic Journal of Political Economy, 31: 99-109.

Kahneman, D. and Tversky, A. (1979). Prospect Theory: An Analysis of Decision under Risk. Econometrica, 47(2), http://www.jstor.org/stable/1914185?origin=crossref (12.09.2017).

Kalleberg, A.L., Reskin, B.F. and Hudson, K. (2000) Bad jobs in America: standard and non-standard employment relations and job quality in the United States. American Sociological Review, 65(2): 256-278, https://doi.org/10.2307/2657440

Kauffman Foundation Report (2017). Zero Barriers: Three Mega Trends Shaping the Future of Entrepreneurship.

Kirzner, I.M. (1973). Competition and Entrepreneurship. Chicago: The University of Chicago Press. 
Kirzner, I.M. (1982). Uncertainty, discovery, and human action: A study of the entrepreneurial profile in the Misesian system. In: I.M. Kirzner (ed.), Method, Process and Austrian Economics. Canada DC Heath.

Kirzner, I.M. (2008). The Alert and Creative Entrepreneur: A Clarification, IFN Working Paper No. 760, 2008, Research Institute of Industrial Economics, August 11.

Klein, P.G. (2007). Organizations and Markets. Hayek and Entrepreneurship, https://organizationsandmarkets.com/2007/11/07/hayek-and-entrepreneurship/ (3.10.2017).

Klein, P.G. (2010). The Capitalist and The Entrepreneur. Essays on Organizations and Markets, Mises Institute, http://store.mises.org/Capitalist-and-The-Entrepreneur-The-P10373.aspx (10.10.2017).

Knight, F.H. (1921). Risk Uncertainty and Profit. Signalman Publishing.

Kreft, S.F. and Sobel, R.S. (2003). Public Policy, Entrepreneurship, and Economic Growth. West Virginia University Entrepreneurship Center Working Paper, http://www.be.wvu.edu/ec/research.htm (29.10.2017).

Krueger, N.F. and Brazeal, D.V. (1994). Entrepreneurial Potential and Potential Entrepreneurs. Entrepreneurship Theory and Practice, Spring: 91-104, https://doi.org/10.1177/104225879401800307

Kshetri, N. (2014). Global Entrepreneurship: Environment and Strategy. Routledge.

Kumar, K.A. and Raj, J.R. (2013). Driving the Economy through Innovation and Entrepreneurship: Emerging Agenda for Technology Management. Springer, New Delhi, Heildelberg.

Kumar, S.A., Poornima, S.C.M., Abraham, K. and Jayashree, K. (2003). Entrepreneurship Development, New Age International Publishers. New Delhi.

Kunasz, M. (2014). Analiza determinant wyboru momentu rozpoczęcia własnej działalności gospodarczej. Management and Business Administration. Central Europe, 22(2): 65-79, https://mbace.eu/resources/html/article/details?id=2006 (9.11.2017).

Kuratko, D.F. (2016). Entrepreneurship: Theory, Process and Practice. Cengage Learning, $10^{\text {th }} \mathrm{ed}$.

Landstrom, H. (2010). Pioneers in Entrepreneurship and Small Business Research. Heidelberg: Springer.

Leibenstein, H. (1968). Entrepreneurship and Development. The American Economic Review, 58(2): 72-83.

Louie, A.M., Ostry, A.S., Quinlan, M., Keegel, T., Shoveller, J. and LaMontagne, A.D. (2006). Empirical study of employment arrangements and precariousness in Australia. Relations Industrielles/ Industrial Relations, 61(3): 465-486, https://doi.org/10.7202/014186ar

Marshall, A. (1890). Principles of Economics. An Introductory volume, https:/eet.pixel-online.org/files/etranslation/original/Marshall,\%20Principles\%20of\%20Economics.pdf

McDaniel, B.A. (2005). A Contemporary View of Joseph A. Schumpeter's Theory of the Entrepreneur. Journal of Economic Issues, 39(2): 485-489, https://doi.org/10.1080/00213624.2005.11506826

McKeown, T. and Phillips, K. (2014). Self-employment or entrepreneurship: What's in a name? (Perhaps quite a lot?). Small Enterprise Association of Australia and New Zealand 27th Annual SEAANZ Conference Proceedings,

http://www.seaanz.org/sites/seaanz/documents/2014SEAANZConference/SEAANZ-2014-McKeown-Phillips.pdf (11.09.2017).

Meadows, M. (2016). Self-discipline for Entrepreneurs: How to develop and Maintain, Self-Discipline as an Entrepreneur. Meadows Publ.

Millán, J.M., Congregado, E. and Román, C. (2010). Determinants of Self-employment dynamics and their implications on entrepreneurial policy effectiveness . Lecturas de Economía, 72: 45-76.

Mises, L. von (1949). Human Action. In: P.J. Boettke and Ch.J. Coyne (eds.), The Oxford Handbook of Austrian Economics, online (access 28.09.2017). 
Mises, L. von. (1951). Profit and Loss. In Mises, Planning for Freedom. South Holland, Ill.: Libertarian Press.

Mises, L. von. (2000). Human Action: A Treatise on Economics. Ludwig von Mises Institute, http://www.mises.org/humanaction.asp.

Mosakowski, E. (1998). Entrepreneurial Resources, Organizational Choices, and Competitive Outcomes. Organization Science, 9: 625-643, https://doi.org/10.1287/orsc.9.6.625

Muehlberger, U. (2007). Dependent Self-Employment. Workers on the Border between Employment and Self-employment. Palgrave Macmillan, https://doi.org/10.1057/9780230288782

Mühlböck, M., Warmuth, J.R., Holienka, M. and Kittel, B. (2017). Desperate entrepreneurs: no opportunities, no skills. International Entrepreneurship and Management Journal, https://doi.org/10.1007/s11365-017-0472-5

Noga, A. (2009). Teorie przedsiębiorstw. Warszawa: PWE.

Nooteboom, B. (2002). Innovation and diffusion in small firms: Theory and evidence, Entrepreneurship. Critical perspective on business and management. London: Routledge.

OECD - Missing Entrepreneurs (2015). Self-employment and Entrepreneurship. Paris: OECD Publishing.

OECD Economic Surveys Poland (2014). Paris: OECD Publishing.

OECD Employment Outlook (2016). Paris: OECD Publishing.

OECD Entrepreneurship at a glance (2011). Paris: OECD Publishing.

OECD Entrepreneurship at a glance (2017). Paris: OECD Publishing.

Parker, S.C. (2009). The Economics of Entrepreneurship. UK: Cambridge University Press, https://doi.org/10.1017/CBO9780511817441

Peneder, M. (2009). The Meaning of Entrepreneurship: A Modular Concept, Journal of Industry, Competition and Trade, 77, https://doi.org/10.1007/s10842-009-0052-7

Perulli, A. (2003). Economically Dependent/Quasi-subordinate (Parasubordinate) Employment: Legal, Social and Economic Aspects. Brussels: European Commission.

Piecuch, T. (2010). Przedsiębiorczość. Podstawy teoretyczne. Warszawa: Wydawnictwo CH Beck.

Propstmeier, J. (2011). Antecedents of Entrepreneurial Behavior - Opportunity Recognition, Entrepreneurial Intention and The Role of Human Capital, Inaugural Dissertation. Munchen: Ludwig-Maximilians Universitat, Munchen.

Purcell, K. (2000). Changing boundaries in employment and organizations. In: K. Purcell (ed.), Changing Boundaries in Employment. Bristol: Bristol Academic Press.

Reich, R.B. (1987). Entrepreneurship reconsidered: The team as hero. Harvard Business Review, May.

Ricketts, M. (2006). Theories of entrepreneurship: historical development and critical assessment. In: M. Casson, B. Yeung, A. Basu and N. Wadeson (eds.), The Oxford Handbook of Entrepreneurship. Oxford: Oxford University Press.

Robinson, D.A., Goleby, M. and Hosgood, N. (2006). Entrepreneurship as a Values and Leadership Paradigm. Regional Frontiers of Entrepreneurship Research, November.

Rocha, V.C. (2012). The Entrepreneur in Economic Theory: From an Invisible Man Toward a New Research Field. FEP Working Paper 459, School of Economics and Management, University of Porto.

Rothbard, M. (1995). Classical Economics: An Austrian Perspective on the History of Economic Thought, vol. 2. Hants, U.K.: Edward Elgar.

Rothbard, M.N. (1962) (2004). What is Entrepreneurship? Ludwig von Mises Institute, http://www.mises.org/story/1530 (21.09.2017).

Salgado-Banda, H. (2005). Entrepreneurship and Economic Growth: An Empirical Analysis, Journal of Development Entrepreneurship, 1(12). 
Sauka, A. (2008). Productive, Unproductive, Destructive Entrepreneurship: A Theoretical and Empirical Exploration. William Davidson Institute, Working Paper No. 917.

Schumpeter, J. (1961). Theory of Economic Developments. New York: Oxford University Press.

Shane, S. A. (2003). A General Theory of Entrepreneurship: The Individual-Opportunity Nexus. Cheltenham: Edward Elgar Publishing, https://doi.org/10.4337/9781781007990

Shane, S.A. (2008). The illusions of entrepreneurship: The costly myths that entrepreneurs, investors and policymakers live by. New Haven, CT: Yale University Press.

Shane, S.A. and Venkataraman, S. (2000). The Promise of Entrepreneurship As A Field Of Research. Academy of Management Review, 25(1): 217-226, https://doi.org/10.5465/amr.2000.2791611

Silberzahn, P. (2013). Commitment in the Entrepreneurial Process. A Reconceptualization, Working Paper, https://philippesilberzahn.files.wordpress.com/2011/02/silberzahn-commitment-and-uncertainty-2013-01-13.pdf.

Simon, M. and Houghton, S.M. (2002). The relationship among biases, misperceptions, and the introduction of pioneering products: examining differences in venture decision contexts. Entrepreneurship Theory and Practice, 27: 105-124, https://doi.org/10.1111/1540-8520.00002

Skrzek-Lubasińska, M. and Szaban, J.M. (2017). Nomenclature and Harmonized Criteria for the Self-Employment Categorization. An Approach Pursuant to the Systematic Literature Review (under review, unpublished).

Smith, A. (2007). Badania nad naturq i przyczynami bogactwa narodów. Wydawnictwo Naukowe PWN.

Starnawska, M. (2011). Przedsiębiorczość w kontekście otoczenia instytucjonalnego - refleksje. Master of Business Administration, 1(116): 21-29, https://mbace.eu/resources/html/article/details?id=1877 (9.11.2017).

Swinscoe, A. (2013). Is Patience Something That Entrepreneurs Need To Learn? https://www.forbes.com/sites/adrianswinscoe/2013/08/15/is-patience-something-that-entrepreneurs-need-to-learn/\#6c79dd637b79 (9.11.2017).

Szaban, J. (2016). Rynek pracy w Polsce i w Unii Europejskiej. Warszawa: Difin.

Thaler, R.H. (2015). The Making of Behavioral Economics Allen Lane. Penguin Books.

Timmons, J. (1990). New Venture Creation. Boston: Irvin.

Timmons, J. and Spinelli, S. (2007). New Venture Creation: Entrepreneurship for the 21st Century. New York.

Veblen, T. (1999). The Theory of Business Enterprise Blackmask Online, http://www.businessbuildersbanquet.com/software/veblen2.pdf (11.09.2017).

Vosko, L., Zukewich, N. and Cranford, C. (2003). Precarious jobs: A new typology of employment. Perspective. Statistics Canada no 75-001-XIE 2003.

Vosko, L.F. (2006). Precarious employment: towards an improved understanding of labor market insecurity. In: L.F. Vosko (ed.), Precarious Employment: Understanding Labor Market Insecurity in Canada. Montreal and Kingston: McGill-Queen's University Press.

Wach, K. (2015). Przedsiębiorczość jako czynnik rozwoju społeczno-gospodarczego: przegląd literatury. Przedsiębiorczość - Edukacja, 11: 24-36, https://doi.org/10.24917/2729.

Wall, S. (2015). Dimensions of Precariousness in an Emerging Sector of Self-Employment: A Study of Self-Employed Nurses. Gender, Work and Organization, 22(3): 221-236, https://doi.org/10.1111/gwao.12071

Weber, M. (1985). The Protestant Ethic and the Spirit of Capitalism. Allenand Unwin.

Weigl., T. (2008). Strategy, Structure and Performance in Transition Economy. An Institutional Perspective on Configuration in Russia. Springer Gabler Edition Wissenshaft. 
Williams, N. and Williams, C.C. (2011). Beyond necessity versus opportunity entrepreneurship. Some lessons from English deprived urban neighbourhoods. International Entrepreneurship and Management Journal, 1.

Venkataraman, S. (1997). The distinctive domain of entrepreneurship research. In: J. Katz (ed.), Advances in entrepreneurship, firm emergence and growth, 3 119-138. Greenwich, CT: JAI Press. 